Vol. 18 (2009): 477-493.

\title{
Modelled impacts of mitigation measures on greenhouse gas emissions from Finnish agriculture up to 2020
}

\author{
Kristiina Regina $^{1}$, Heikki Lehtonen ${ }^{2}$, Jouni Nousiainen ${ }^{3}$ and Martti Esala ${ }^{1}$ \\ ${ }^{1}$ MTT Agrifood Research Finland, Plant Production Research, FI-31600 Jokioinen, Finland, \\ ${ }^{2}$ MTT Economic Research, Luutnantintie 13, FI-00410 Helsinki, Finland, \\ ${ }^{3}$ MTT Biotechnology and Food Research, FI-31600 Jokioinen, Finland, \\ email: firstname.lastname@mtt.fi
}

\begin{abstract}
Emission scenarios based on integrated quantitative modelling are a valuable tool in planning strategies for greenhouse gas mitigation. By estimating the potential of individual mitigation measures to reduce greenhouse gas emissions, resources can be targeted to the most promising policy measures. This paper reports two agricultural emission scenarios for Finland up to year 2020, one baseline scenario (Scenario 1) based on the projected agricultural production levels determined by markets and agricultural policy and one with selected mitigation measures included (Scenario 2). Measures selected for the analysis consisted of 1) keeping agricultural area at the current level, 2) decreasing the proportion of organic soils, 3) increasing the proportion of grass cultivation on organic soils and 4) supporting biogas production on farms. Starting from 2005, the emissions of nitrous oxide and methane from agriculture would decrease $2.3 \%$ in Scenario 1 by 2020 whereas the respective decrease would be $11.5 \%$ in Scenario 2 . According to the results, mitigation measures targeted to cultivation of organic soils have the largest potential to reduce the emissions. Such measures would include reducing the area of cultivated organic soils and increasing the proportion of perennial crops on the remaining area.
\end{abstract}

Key-words: Greenhouse gas emissions, emission projections, integrated modelling, methane, nitrous oxide, agricultural policy, mitigation, agricultural sector modelling 
Regina, K. et al. Greenhouse gas mitigation in Finnish agriculture

\section{Introduction}

Greenhouse gas (GHG) emissions from agriculture constitute almost $10 \%$ of the total emissions of Finland (Statistics Finland 2009). Due to the international conventions aiming at reduction of the emissions also the agricultural sector has to contribute to the national mitigation efforts. The overall reduction target for Finland, according to the Kyoto Protocol under the UN Framework Convention on Climate Change (UNFCCC), is to cut the emissions to the level of the year 1990 in the averaging period of 2008-2012. In addition to that, the EU member states have reached an agreement to aim at a $20 \%$ reduction in greenhouse gas emissions in 2020 compared to 1990 . The burden has been shared between the member states and emitting sectors so that e.g. in Finland the aim for sectors not part of the emissions trading scheme is to reach a collective $16 \%$ reduction in the time period 2005-2020. In order to respond to these EU level targets of GHG mitigation, Finnish Government has recently published a Climate and Energy Strategy in which the agricultural sector is given a $13 \%$ reduction target in the GHG emissions in 2005-2020. The strategy does not define which measures are to be used to reach the target but outlines important issues to be elucidated, e.g. the possible measures to reduce emissions on organic soils and in animal production.

Emission scenarios can be used as a tool for the planning of national climate strategies if the effects of mitigation measures are included in the scenarios. The selection of mitigation measures has to be done taking into account the political, social and economic constraints. There is often a large difference between the technical potential of a mitigation measure and the realistic achievable level (Smith et al. 2007). Only few countries have GHG mitigation strategies designed for agriculture, and the achieved emission reductions are often due to other policies (e.g. prevention of water pollution). However, specific strategies for agriculture may become necessary (Neufeld and Schäfer 2008). Analysis combining economic modelling with GHG modelling can be used to reveal the connec- tions between policies and GHG emissions (Sands and Leimbach 2003, Neufeld et al. 2006).

Our aim was to model the impact of selected mitigation measures to reduce the emissions of nitrous oxide $\left(\mathrm{N}_{2} \mathrm{O}\right)$ and methane $\left(\mathrm{CH}_{4}\right)$ from agriculture. Carbon dioxide emissions from soils are not covered and thus these estimates are restricted to the emissions sources reported under the reporting sector "Agriculture" of the UNFCCC. Two greenhouse gas emission scenarios for agriculture in Finland were developed by applying an agricultural sector model together with a model for GHG calculation. The economic sector model produced development paths of agricultural production under market and policy scenarios, including GHG mitigation measures with their respective costs. The GHG emissions were calculated using an emission calculation model utilizing IPCC parameters and equations as well as parameters based on national research. This approach is capable of taking into account emissions from major emission sources in agriculture as well as impacts of policy measures and main driving mechanisms on them.

\section{Materials and methods}

Two sets of major driving forces of agricultural GHGs were taken into account: (1) Changes in agricultural production and land use due to changing agricultural policy and markets; (2) Specific selected GHG mitigation measures such as restrictions on total agricultural area or land use and biogas production. In order to calculate the impact of both sets of driving forces on GHGs an economic sector model (Dremfia) and a model for specific GHG calculation (Agrigas) were applied. The Dremfia model was used in simulating the economic behaviour of agricultural markets under changing policies and markets implying changes in regional production structure and land use. The data from the Dremfia model was used as input data for the Agrigas model used to calculate emissions of $\mathrm{CH}_{4}$ and $\mathrm{N}_{2} \mathrm{O}$ from agricultural sources applying the IPCC methodology. 
Vol. 18 (2009): 477-493.

\section{Dremfia model}

Dremfia is a dynamic recursive model for simulating agricultural production and markets from 1995 up to 2020 (Lehtonen 2001, 2004). The underlying hypothesis in the model is profit maximising behaviour of producers and utility maximising behaviour of consumers under competitive markets. According to microeconomic theory, this leads to welfare maximising behaviour of the agricultural sector. Decreasing marginal utility of consumers and increasing marginal cost per unit produced in terms of quantity lead to equilibrium market prices which are equal to marginal cost of production on competitive markets. Each region specialises to products and production lines of most relative profitability, taking into account profitability of production in other regions and consumer demand. This means that total use of different production resources, including farmland, on different regions are utilised optimally in order to maximise sectoral welfare, taking into account differences in resource quality, technology, costs of production inputs and transportation costs (spatial price equilibrium; Takayama and Judge 1971). If production resources in different regions differ substantially in terms of GHG emissions - due to soil types and crop yields, for example - the regional production structure is a very significant issue in GHG emissions, not only overall production volume.
Sector models of agriculture simulating competitive markets under fixed resources and production technology have long been common tools in agricultural economics. Farmland resources are typically assumed fixed while quasi-fixed inputs, such as buildings and machinery, have a life-span of typically 10-30 years. Changes in technology, regional production structure and land use, affected by public policies, may facilitate sizable GHG reductions in agriculture over time. While changes in quasi-fixed inputs such as production buildings and machinery, whose demand is weak in any alternative use, can be modelled endogenously in agricultural sector models, modelling changes in farmland area is more difficult since other sectors of the economy are using land resources as well. Hence in our sector modelling approach, exogenous assumptions and trends have been given for total available farmland area whereas structural and technical change in animal production, implying various changes in land use trough feed demand, has been modelled endogenously.

Dremfia model consists of two main parts: (1) a technology diffusion model which determines sector level investments in different production technologies; (2) An optimisation routine simulating annual production decisions (within the limits of fixed factors) and price changes, i.e. supply and demand reactions, by maximising producer and consumer surplus subject to regional product balance and resource (land and capital) constraints (Fig. 1.).

\begin{tabular}{|c|c|c|}
\hline & Market model & Policy scenarios \\
\hline \multirow{2}{*}{\multicolumn{2}{|c|}{$\begin{array}{l}\text { MAX: producer and consumer surplus } \\
\text { annual market equilibrium } \\
\text { - different yields and inputs in regions } \\
\text { - feed use of animals changes endogenously } \\
\text { constraints on energy, protein and } \\
\text { roughage needs of animals } \\
\text { non-linear milk yield functions for dairy } \\
\text { cows } \\
\text { domestic and imported products are } \\
\text { imperfect substitutes } \\
\text { processing activities of milk and sugar } \\
\text { export cost functions }\end{array}$}} & $\begin{array}{l}\text { Crop yield functions } \\
\text { - optimal level of fertilisation }\end{array}$ \\
\hline & & $\begin{array}{l}\text { Steering module } \\
\text { - boundaries for land use variables; } \\
\text { validated to observed data } \\
\text { - trends in consumption } \\
\text { - inflation } \\
\text { - increase in crop and animal yield } \\
\text { potential }\end{array}$ \\
\hline & $t=t+1$ & \multirow{2}{*}{$\begin{array}{l}\text { Model of technology diffusion } \\
\text { - endogenous sector level } \\
\text { investment and technical change } \\
\text { - investments depend on relative } \\
\text { profitability and accessibility of } \\
\text { each technique }\end{array}$} \\
\hline \multicolumn{2}{|r|}{$\begin{array}{ll}\text { Results/Initial values } \\
\text { land use } & \text { consumption } \\
\text { imports } & \text { exports } \\
\text { transportation } & \end{array}$} & \\
\hline
\end{tabular}

Fig. 1. Basic structure of the Dremfia model. 


\section{AGRICULTURAL AND FOOD SCIENCE}

\section{Regina, K. et al. Greenhouse gas mitigation in Finnish agriculture}

Production activities include number of different animals, hectares under different crops and set-aside, feed diet composition, chemical and manure fertiliser use and the resulting crop yield level. Products and intermediate products may be transported between the regions at certain transportation costs. In a dynamic recursive model the parts (1) and (2) interact each year so that prices from the market simulating optimisation model enter the technology diffusion model representing sector level investments in each region, and changes in animal production capacities of different techniques enter the market model in the following year.

Technical change and investments, which imply evolution of farm size distribution and production capital in regions, are modelled as a process of technology diffusion described by Soete and Turner (1984). Two crucial aspects about diffusion and adaptation behaviour are included: first, the profitability of a new technique, and second, the risk and uncertainty involved in adopting a new technique. The information about and likelihood of adoption of a new technique will increase as its use becomes widespread.

The likelihood of adoption of a new technique (let us call it $f_{\beta \alpha}$ ) is made proportional to the fractional rate of profit increase in moving from technique $\alpha$ to technique $\beta$, i.e., $f_{\beta \alpha}$ is proportional to $\left(r_{\beta}-r_{\alpha}\right) / r_{\alpha}$, where $r_{\alpha}$ is the rate of return for technique $\alpha$ and $r_{\beta}$ is the rate of return for technique $\beta$. The second aspect is modelled by letting $f_{\beta \alpha}$ be proportional to the ratio of the capital stock in $\beta$ technique $\left(K_{\beta}\right)$ to the total capital stock $K$ (in a certain agricultural production line), i.e., $K_{\beta} / K$. The total investments to $\alpha$ technique, after simplification, is

$$
I_{\alpha}=\sigma\left(Q_{\alpha}-w L_{\alpha}\right)+\eta\left(r_{\alpha}-r\right) K_{\alpha}
$$

where $\sigma$ is the savings rate (proportion of economic surplus re-invested in agriculture), $\eta$ is the farmers' propensity to invest in alternative techniques, $Q_{\alpha}$ is the total production-linked revenue for technique $\alpha$, $w$ is a vector of input prices, $L_{\alpha}$ is a vector of variable production factors of technique $\alpha$, and $r$ is the average rate of return on all techniques.
If a technique is highly profitable, it will tend to attract investments and, conversely, if it is relatively less profitable, investments will decline. On the other hand, all investable surpluses (revenues minus costs of each technique) may not be invested in best performing techniques immediately but some part of the surplus is invested in techniques which are wider spread and hence more accessible for farmers than new more profitable techniques where capital is few (there is less information available on the performance and risks of new techniques). While parameter $\sigma$ determines the overall level of capital invested in the sector, the parameter $\eta$ defines how strongly farmers invest in alternative more profitable techniques, instead to their existing technique. In fact choosing a unique combination of these parameters one can calibrate the simulated overall capital and capital distribution exactly to the observed capital and its distribution in different techniques. Knowing the price of investment necessary for one animal (price of an animal place in a specific type of a cattle house, for example), one may also directly derive the distribution of animals in different production techniques, or farm size classes, if 'technique' is interpreted as different production arrangements and their costs per animal in different farm size classes. Hence the technology diffusion model used here is attributed to three difference farm size classes of dairy farms: farms with 1-19 cows (labour intensive production), farms with 20-49 cows (semi-labour intensive production), and farms with 50 cows or more (capital intensive production). The parameters $\eta$ and $\sigma$ are adjusted accordingly to calibrate the observed number of animals and their distribution to different farm size classes reported in official statistics.

To summarise, the investment function (1) is an attempt to model the behaviour of farmers whose motivation to invest is greater profitability but who, nevertheless, will not adopt the most profitable technique immediately because of uncertainty and other retardation factors. Overall, in a multi-regional model such as Dremfia the technology diffusion scheme simulates the observed gradual concentration of animal production to regions where the share of large and most likely relatively efficient 
Vol. 18 (2009): 477-493.

farms is high already. The endogenous evolution of farm size structure and technology is important in simulating regional shifts of production due to policy changes, notably milk quotas and their gradual abolition, influencing capacity of different regions to increase production..

The investment model and resulting production capacity changes is however closely linked to market model determining production (including land use, fertilisation, feeding of animals, and yield of dairy cows, for example), consumption and domestic prices. Our market model is a typical spatial price equilibrium model (see e.g. Cox and Chavas 2001), except that no explicit supply functions are specified, i.e. supply is a primal specification). Furthermore, foreign trade activities are included in Dremfia. The Armington assumption (Armington 1969 ) is used. Imported and domestic products are imperfect substitutes, i.e., endogenous prices of domestic and imported products are dependent. This means that exogenously given EU prices influence domestic prices, but the domestic prices may be different from the EU prices, depending on the balance between supply and demand on do- mestic markets. For example, decreasing domestic supply may drive up domestic prices slightly even if EU prices were stable, because imported products, especially beef and many dairy products, are not seen as perfect substitutes to domestic ones by consumers.

Four main areas are included in the model: Southern Finland, Central Finland, Ostrobothnia (the western part of Finland), and Northern Finland. Production in these areas is further divided into sub-regions on the basis of the support areas. In total, there are 17 different production regions. This allows a regionally disaggregated description of policy measures and production technology. Concerning GHG emissions and possible climate policies, organic soils are separated from other soils in Dremfia. Depending on selected policy to be analysed organic soils can be excluded from cultivation completely or they can be used only as grasslands. These options can be easily modelled in an optimisation model with explicit resource constraints. The share of organic soils of all farmland varies between $2-29 \%$ in different regions (Table 1).

Table 1. Total farmland area (ha) 2006 and estimated share (\%) of organic soils in Dremfia spatial aggregation.

\begin{tabular}{lccc}
\hline Region & Support zone & Total farmland, ha & Organic soils, \% \\
\hline Southern Finland & A & 364739 & 4.3 \\
\hline Southern Finland, Yläneenjoki & A & 34500 & 4.3 \\
Southern Finland & B & 699777 & 8.8 \\
Southern Finland & BS & 8936 & 2.0 \\
Southern Finland & C1 & 36031 & 13.8 \\
Southern Finland & C2 & 35776 & 9.9 \\
Central Finland & B & 13062 & 3.4 \\
Central Finland & C1 & 152234 & 10.2 \\
Central Finland, Taipaleenjoki & C1 & 12000 & 10.2 \\
Central Finland & C2 & 200474 & 10.2 \\
Central Finland & C2P & 36405 & 11.1 \\
Ostrobothnia & C1 & 284043 & 19.6 \\
Ostrobothnia & C2 & 323555 & 23.8 \\
Northern Finland & C2P & 20514 & 20.4 \\
Northern Finland & C3 & 65632 & 29.0 \\
Northern Finland, Simojoki & C3 & 6386 & 29.0 \\
Northern Finland & C4 & 9021 & 29.0 \\
Whole country & & 2303148 & 12.0
\end{tabular}




\section{Regina, K. et al. Greenhouse gas mitigation in Finnish agriculture}

Use of variable inputs, such as fertilisers and feed stuffs, are dependent on agricultural product prices and fertiliser prices through production functions. The nutrients from animal manure are explicitly taken into account in the economic model. Feeding of animals may change in the short-term within certain bounds imposed by fixed production factors and animal biology, provided that nutrition requirements, such as energy, protein, phosphorous and roughage needs, are fulfilled. Specific production functions are used to model the dependency between the average milk yield of dairy cows and the amount of the grain based feed stuffs used in feeding. The yield of dairy cows responds to price changes of milk and feed stuffs. In this study, however, relative prices, mostly driven by EU level and global price changes, and feeding of animals are not much affected by climate policies analysed.

Milk quotas, which constrain milk production at farm and country level, are traded within three separate areas in the model. Within each quota trade area, the sum of bought quotas must equal the sum of sold quotas. The price of the quota is the weighted sum of the shadow values of an explicit quota constraint in each sub-region. The observed milk quota prices have served a valuable reference point in the model validation. There are 18 different processed milk products and their regional processing activities in the model.

The overall Dremfia model replicates very closely the ex post production in 1995-2007. The model is built to reach a steady-state equilibrium, long- and medium-term changes in aggregate amounts and regional location, in a 10-15 year period given no further policy changes. There is a gradual adjustment built-in in the model as fixed production factors and animal biology make immediate adjustments costly. Non-linear production functions, estimated using empirical datasets and statistical methods, are concave, i.e. the marginal productivity is decreasing with output. The steadystate equilibria found at the whole country level are also due to limited domestic consumption of food stuffs and expensive exports because of low EU price level compared to the production and transportation costs. Another reason for steady states in 10-15 year period is the Armington assumption, i.e. the imperfect substitution between domestic and imported products. A more detailed presentation of the model can be found in Lehtonen (2001, 2004).

\section{Agrigas model}

The model used for calculating annual agricultural greenhouse gas emissions for the national greenhouse gas inventory submitted to the UNFCCC is an Excel spreadsheet that calculates the emissions from three different source categories: enteric fermentation $\left(\mathrm{CH}_{4}\right)$, manure management $\left(\mathrm{CH}_{4}, \mathrm{~N}_{2} \mathrm{O}\right)$ and agricultural soils $\left(\mathrm{N}_{2} \mathrm{O}\right)$. The calculation methods are described in detail in the annual inventory report (Statistics Finland 2009).

Methane emissions from enteric fermentation of cattle were calculated by using the Tier 2 methodology of the Intergovernmental Panel on Climate Change (IPCC) (IPCC 1997, Penman et al. 2000). Cattle species included in the inventory are dairy cows, suckler cows, bulls, heifers and calves. In the IPCC methodology, an emission factor for each cattle species is calculated by using information about the annual gross energy intake by each species. It is assumed that $6 \%$ of the gross energy intake of cattle is converted to $\mathrm{CH}_{4}$. Other livestock included in the calculations were horses, pigs, goats, sheep and reindeer. For the other livestock species, IPCC default emission factors (Penman et al. 2000) were used except for sheep and reindeer for which there exist national emission factors (Statistics Finland 2009).

Methane emissions from manure management were calculated according to the IPCC guidelines (Penman et al. 2000). Livestock species included were cattle (dairy cows, suckler cows, bulls, heifers, calves), horses, swine, sheep, goats, poultry, fur animals and reindeer. The Tier 2 methodology was used with an emission factor for each animal group calculated with the IPCC equations and IPCC default parameters (maximum methane producing potential, methane conversion factor, ash content of manure and volatile solids excretion for other livestock). The emission factors were calculated 
Vol. 18 (2009): 477-493.

by estimating the amount of volatile solids excreted in manure annually and multiplying this with the maximum $\mathrm{CH}_{4}$ producing potential for each livestock species. The effects of manure management system on $\mathrm{CH}_{4}$ production has been calculated by estimating the proportion of manure treated in each manure management system and multiplying this with the specific conversion factor (MCF) for each manure management system (slurry, pasture, solid storage).

Nitrous oxide emissions from manure management were calculated according to the IPCC methodology (Penman et al. 2000). The amount of $\mathrm{N}$ excreted annually by each animal species was calculated as in Grönroos et al. 2009. This amount was divided between different manure management systems (slurry, pasture, solid storage) and the IPCC default emission factors $0.02 \mathrm{~kg} \mathrm{~N}_{2} \mathrm{O}-\mathrm{N} /$ $\mathrm{kg} \mathrm{N}$ for pasture and solid storage and $0.001 \mathrm{~kg}$ $\mathrm{N}_{2} \mathrm{O}-\mathrm{N} / \mathrm{kg} \mathrm{N}$ for slurry were used to calculate the emissions.

Nitrous oxide emissions from agricultural soils were calculated by using the IPCC methodology described in Penman et al. (2000). Direct emission sources include mineral fertilisers, manure, crop residues, nitrogen fixing crops, application of sewage sludge and cultivation of organic soils. For organic soils the national emission factors 4.1 and $11.7 \mathrm{~kg} \mathrm{~N}_{2} \mathrm{O}-\mathrm{N} \mathrm{ha}^{-1} \mathrm{a}^{-1}$ were applied for grass and other crops, respectively (Monni et al. 2007). The emission factor $0.0125 \mathrm{~kg} \mathrm{~N} \mathrm{~N}_{2} \mathrm{O}-\mathrm{N} / \mathrm{kg} \mathrm{N}$ applied was used for direct emissions, not the new one $(1 \%)$ suggested by the 2006 Guidelines of the IPCC since the new guidelines are not taken into use yet. For calculating indirect emissions from atmospheric deposition, the amount of $\mathrm{NH}_{3}$ and $\mathrm{NO}_{\mathrm{x}}$ volatilized from synthetic fertilisers and manure was estimated. The fraction volatilized as $\mathrm{NH}_{3}$ and $\mathrm{NO}_{\mathrm{x}}$ from synthetic fertilisers was $0.6 \%$ and that for manure 30\% (Statistics Finland 2009). For indirect emissions from leaching and run-off, the amount of $\mathrm{N}$ leached annually was estimated. Fraction of nitrogen leached was a national value $15 \%$ (Rekolainen et al. 1993). The emission factor for atmospheric deposition was $0.01 \mathrm{~kg} \mathrm{~N}_{2} \mathrm{O}-\mathrm{N} / \mathrm{kg}$ $\mathrm{NH}_{4}-\mathrm{N} \& \mathrm{NO}_{\mathrm{X}}-\mathrm{N}$ and that for leaching and run-off $0.025 \mathrm{~kg} \mathrm{~N} \mathrm{~N}_{2} \mathrm{O}-\mathrm{N} / \mathrm{kg} \mathrm{N}$.

\section{Assumptions for the emission scenarios}

Two different estimates of GHG emissions in the future years were made. Scenario 1 was a baseline scenario with no impacts of mitigation measures included. Scenario 2 has the same basic assumptions as Scenario 1 but it also reflects the effects of specific measures for $\mathrm{GHG}$ emission reduction. For Scenario 2, selected GHG mitigation measures were implemented first in Dremfia sector model, on the top of the expected changes in agricultural policies and markets.

We assumed the same agricultural and agrienvironmental policy in both emission scenarios. However, the agricultural policy itself is not unchanged but subject to changes as agreed in the CAP reform in 2003 (Council of the EU 2003) and CAP "health check reform" agreed on in 2008 (European Commission 2009, MMM 2008a). The major changes in agricultural policy are the abolition of milk quotas in the EU in 2015, after gradual increase in milk quotas by $1 \%$ annually in 2009 2013. We did not take into account the abolition of obligatory set-aside as agreed by the 2008 CAP reform agreement since it has affected only $3.6 \%$ of the farmland area in Finland. The CAP premia for bulls and suckler cows remain coupled to production since Finland got the right to pay $10 \%$ of all CAP payments coupled to production $(3.5 \%$ in other EU member countries). Another major change in agricultural policy is the decoupling of the national support earlier paid per head of pigs and poultry animals (MMM 2008b). Since that form of support has been significant (up to $15 \%$ of farm revenues on pig and poultry sectors), the impact of the decoupling decisions required by European Commission in 2008 is likely to decrease production. The other forms of national support paid per litre of milk and heads of other bovine animals except dairy cows were assumed unchanged in terms of the overall budget available for national payments. We did not take into account that climate change itself can increase crop production in the future and lead to need of less area since this effect was estimated non-significant before year 2020 (Tubiello et al. 2007). 


\section{Regina, K. et al. Greenhouse gas mitigation in Finnish agriculture}

Prices of milk products were predicted to remain at the level of 2006 until 2010. As the milk quotas were assumed to rise and then be abolished the prices of milk products after 2015 were estimated to be $15 \%$ lower than in 2006 due to significantly increased internal competition on the EU dairy sector. However this $15 \%$ reduction in dairy product prices is assumed to take place on the EU market prices for dairy products, and the actual impact on the Finnish dairy product prices and milk producer prices is likely to be slightly lower due to imperfect product substitution. Prices of cereals in 2007-2020 were predicted to be $30 \%$ higher than in 2001-2005 (OECD 2008). The prices of poultry meat, beef and pork were estimated to increase $40 \%, 15 \%$ and $20 \%$, respectively, following OECD (2008).

Such price scenarios, together with assumptions of non-decreasing agricultural subsidies after 2009, can be considered optimistic from farmers' point of view. Decreasing production linked national payments and significantly less optimistic price scenarios for meat and milk would very likely cause at least a slight downturn in agricultural production in Finland (see for example Lehtonen et al. 2005). We have not analysed here such policy and market scenarios which would lead to decreasing trend of GHG emissions without any additional measures. The actual challenge for agriculture, under prospects of strong global demand for food, however is how to produce food while decreasing the GHG emissions. We concentrate on this aspect in this paper.

The emissions for the years 1990-2006 were the same as reported for the Climate Convention. For the future projections, results of the Dremfia model were used as input data for the model Agrigas. Dremfia produced most of the input data for the GHG modelling: area of cultivated soils, use of mineral fertilisers and the numbers of most important animal species. In addition, development of some parameters in the future were estimated as expert judgments: spread of manure management systems in the future, use of sewage sludge as fertiliser, numbers of horses (slightly increasing population), sheep, fur animals, reindeer and turkeys (stable population), and the development of the weight of cattle.
Milk production and weights of animals were predicted to develop as in 1990-2005. A linear increase in milk production from $7700 \mathrm{~kg}$ to $9750 \mathrm{~kg}$ per animal and year in the time period 2005-2020 was applied. The weight of cattle was assumed to increase $2-10 \%$ in $2005-2020$. For example the weight of dairy cows was set to increase $8 \%$ and that for bulls $2 \%$ since the carcass weights of dairy breed bulls $(90 \%$ of bulls in Finland are of dairy breed) cannot be increased anymore without downgrading in the quality of beef after a strong increase in slaughter weights already in 2000-2006. In the scenarios, the emission factors for cattle changed annually whereas those for other species remained at the current level. No big technological changes in manure management were assumed but the share of slurry systems was predicted to increase from 47 to $90 \%$ for dairy cows, from 30 to $40 \%$ for other cattle and from 60 to $70 \%$ for pigs until 2020. In Scenario 1, we assumed that the proportion of organic soils of the total cultivated area would remain the same as in 2006 but as the agricultural area was assumed to grow in this scenario, it also caused the area of organic soils to increase. In Scenario 2 , however, there were mitigation measures that prohibited the increase of the area (see below).

For Scenario 2, we applied the same assumptions as described above, but also selected mitigation measures that were thought to be realistic and relatively easy to take into use in the near future. Other criteria for the selection of measures were that a calculation method must exist for the GHG inventory and some statistics should be available about them. Avoiding increase in agricultural area was considered important since less than the current area is required to ensure a sufficient level of food production. As organic soils (peat and mull soils) are the second largest emission source after enteric fermentation, priority was given to measures targeted to them. Due to research activities on organic soils, Finland has specific emission factors for grass cultivation and for other crops (Maljanen et al. 2007). Farmers have recently become increasingly interested in the production of biogas on farms and thus increase in biogas production was also considered as a realistic trend. Mitigation measures selected for Scenario 2 were: 
Vol. 18 (2009): 477-493.

1) Agricultural area stabilized at the level of 2006. Taking new area to cultivation would be possible only if it replaces area taken away from cultivation.

2) Reduction in the area of organic soils. We assumed an annual reduction of 3000 ha in the area of cultivated organic soils. The reduction would be achieved mainly by prohibiting taking of new organic area into agricultural use and afforestation. Also, part of the fields could be taken to peat production and part is gradually converted to mineral soils as the mineralization of the peat continues.

3) Increasing the proportion of grass on organic soils. We assumed an increase in the proportion of grass from $50 \%$ to $80 \%$ in the period $2005-2020$. Since the emissions are caused by mineralization of the peat, all measures that reduce the aeration of the peat decrease the emissions (Oleszczuk et al. 2008). The benefits of grass compared to e.g. cereal cultivation are less frequent tillage and longer period of plant coverage resulting to lower N2O emissions.

4) Increasing biogas production. We assumed that half of the large farms would produce biogas from their total amount of manure (excluding the amount excreted on pastures). A large farm was determined as one with at least 100 dairy cows, 1000 fattening pigs, 330 sows, 24000 laying hens or 60000 broilers. The number of large farms was estimated to increase from the current situation. Our estimate of the potential mitigation was based on the results of Amon et al. (2006) and Clemens et al. (2006) showing that $50-70 \%$ of the $\mathrm{CH} 4$ emissions during storage can be mitigated. We assumed that in addition to the measured potential part of the residual $\mathrm{CH}_{4}$ formed in the storage after the fermentation stage would be collected and utilized, resulting to a $80 \%$ reduction in the storage phase in total.

Mitigation measures 1-3 were explicitly taken into account in the Dremfia sector model as well as in Agrigas model. However the mitigation measure 4 was taken into account only in the Agrigas model since Dremfia model does not include energy markets or costs and benefits of biogas to farmer, necessary to evaluate economic consequences of agricultural biogas production. Hence we only assumed that public investment supports and other policy measures provide full compensation of the costs of biogas production to farmers. In other words we assumed biogas a cost neutral option to farms without any significant effects in input use of agriculture although in reality the costs and benefits of biogas on the use of manure may change and have input substitution effects on agriculture.

\section{Results}

\section{Output of Dremfia for Scenario I}

The model output indicated an increase of $7 \%$ in the total agricultural area and an increase of $15 \%$ in the amount of $\mathrm{N}$ application in mineral fertilisers in 2005-2020 (Table 2). The overall fertilization rate per hectare increased $18 \%$ in 2005-2020. The results showed an increase of $10 \%$ in the future fertilization rate of cereals due to the expected high cereal prices. Accordingly, the crop yield also increased 1-3\% until 2020 accompanied with a moderate increase in the area of cereal crops until 2020. The area of grass remained at the current level and its fertilising rate was at a relatively high level due to the high price of milk. In fact the predicted high prices of milk and cereals would lead to higher rates of fertilisation in the future compared to the observed practice in recent years.

Since we estimated the production-dependent payments for suckler cows and bulls to be continued, the beef production was estimated to diminish relatively less than observed in the recent years. The production of beef was modelled to stabilize at the level of 80 million $\mathrm{kg}$ per year by 2020 . Although the number of suckler cows increased the total amount of cattle was estimated to be reduced by $14 \%$ in 2005-2020 (Table 2). During the same time, pork production was estimated to be reduced by $19 \%$, to the level required for domestic consumption. Poultry production was estimated to stay at the current level despite the decoupling of national payments since domestic consumption was also predicted to increase by approximately $10 \%$ (based on 2008 data this assumed change can be 
Regina, K. et al. Greenhouse gas mitigation in Finnish agriculture

Table 2. The development of the most important parameters determining the emissions in Scenario 1 and Scenario 2.

\begin{tabular}{|c|c|c|c|c|c|c|c|c|}
\hline & \multicolumn{2}{|c|}{1990} & \multicolumn{2}{|c|}{2005} & \multicolumn{2}{|c|}{2010} & \multicolumn{2}{|c|}{2020} \\
\hline & Sc1 & $\mathrm{Sc} 2$ & $\mathrm{Sc} 1$ & $\mathrm{Sc} 2$ & Sc1 & $\mathrm{Sc} 2$ & $\mathrm{Sc} 1$ & $\mathrm{Sc} 2$ \\
\hline Cropland area (kha) & 2271 & 2271 & 2234 & 2234 & 2270 & 2270 & 2390 & 2274 \\
\hline Organic soils (kha) & 366 & 366 & 277 & 277 & 272 & 258 & 287 & 226 \\
\hline Cereals, oilseeds, potatoes (kha) & 1406 & 1406 & 1373 & 1373 & 1261 & 1261 & 1358 & 1341 \\
\hline Grass (kha) & 682 & 682 & 620 & 620 & 605 & 605 & 638 & 639 \\
\hline Set aside (kha) & 183 & 183 & 241 & 241 & 403 & 403 & 395 & 293 \\
\hline $\mathrm{N}$ in mineral fertilisers $(\mathrm{Gg})$ & 228 & 228 & 150 & 150 & 154 & 154 & 173 & 171 \\
\hline Cereals production $(1000 \mathrm{t})$ & 4253 & 4253 & 4064 & 4064 & 3718 & 3718 & 4069 & 4047 \\
\hline Milk production (1000 t) & 2718 & 2718 & 2392 & 2392 & 2261 & 2261 & 2236 & 2234 \\
\hline Milk production $\left(\mathrm{kg} \mathrm{cow}^{-1}\right.$ year $\left.^{-1}\right)$ & 5547 & 5547 & 7505 & 7505 & 8259 & 8259 & 9748 & 9748 \\
\hline Number of cattle $(\times 1000)$ & 1360 & 1360 & 959 & 959 & 875 & 875 & 828 & 827 \\
\hline Number of pigs $(\times 1000)$ & 1394 & 1394 & 1401 & 1401 & 1278 & 1278 & 1138 & 1138 \\
\hline
\end{tabular}

$\mathrm{Sc}=$ scenario

already verified in official statistics). Milk production declined about 5\% from the level of 2005 but the remaining production would satisfy the domestic demand of all milk products. The observed rapid increase of expenses in 2006-2008 as well as increases in area-based subsidies due to earlier CAP reforms decrease the motivation for milk production and reduce the profit of investments on animal production.

\section{Output of Dremfia for Scenario 2}

The model output for Scenario 2 indicated a steady total cropland area together with a slightly smaller area of cereals and a similar area of grass in 2020 compared to Scenario 1 (Table 2). The total amount of $\mathrm{N}$ in mineral fertilisers was almost at the same level as in the baseline scenario resulting to a $17 \%$ higher fertilising rate per hectare in 2020 compared to 2005. This means that mineral fertilisers and land area are not any close substitutes in cereals cultivation. This is because labour and capital costs per hectare are relatively high compared to the value of crop.
The simulation also showed that restricting the cropland area to the level of 2006 would not affect the development of animal production in the long run; thus in all livestock types the production would be very close to that of the baseline scenario.

Allocating organic lands for grass cultivation as a climate policy measure means decreasing cereals cultivation on organic farmland and increasing cereals cultivation on mineral farmland. Grassland area (including bioenergy grasses) or green fallow would increase on organic farmland. The green fallow or energy crop options mean that farmers are not obliged to carry on grassland based milk or beef cattle production on organic soils but they may cease cattle production entirely and/or leave organic lands as set-aside. In fact scenario 2 leads to increasing green set-aside areas or other low intensity grasslands on regions which have high shares of organic soils out of total farmland, while cereal areas increase and set-aside areas decrease on regions with little organic soils. However the magnitude in the land use change on regions with high shares of organic soils is not uniform in Scenario 2 but varies a lot due to different initial structure, intensity and competitiveness of animal production. When summing up the grassland areas and cereals areas 
Vol. 18 (2009): 477-493.

over all regions, Scenario 2 induces relatively small changes in the overall land use.

Restricting cereal cultivation on organic lands did cause some additional costs (such as manure spreading costs and costs of purchased feed on regions where organic soils are common) and small temporary declines in overall milk production. However the decline in milk production is hardly visible at all anymore in 2020 . This is because the model of technology diffusion facilitates increasing rate of production expansion on regions where the share of organic soils is small. The main result from the Dremfia model is that the EU prices of agricultural commodities as well as production linked subsidies affect equilibrium level of commodity production more strongly than the actual GHG mitigation measures analysed in this study.

\section{GHG emission estimates in Scenario I}

Agricultural greenhouse gas emissions in Scenario 1 decreased from $5.60 \mathrm{Tg} \mathrm{CO}_{2}$ eq. in 2005 to $5.47 \mathrm{Tg}$ in 2020 which corresponds to a $2.3 \%$ decrease (Table $3)$. The decreasing trend observed in 1990-2006 would continue until the year 2016 after which the total emissions would start to increase due to the predicted increase in the use of mineral fertilisers and a higher number of cattle combined with their rising emission factors (Fig. 2).

The number of cattle in 2020 would, however, be lower than currently (Table 3). For $\mathrm{CH}_{4}$ emissions from enteric fermentation, a decrease in the emissions was simulated for the period 2005-2020 due to declining animal numbers (Table 3 ). For example in the case of dairy cattle the number of ani-

Table 3. Estimated GHG emissions in a baseline scenario (Scenario 1) and a policy scenario (Scenario 2) and the difference between the scenarios as $\mathrm{CO}_{2}$ equivalents.

\begin{tabular}{|c|c|c|c|c|}
\hline \multirow[t]{2}{*}{ Emission source } & \multirow{2}{*}{$\begin{array}{c}2005 \\
\operatorname{Tg} \mathrm{CO} 2 \mathrm{eq} . \\
\text { Reported emissions }\end{array}$} & \multicolumn{2}{|c|}{$\begin{array}{c}2020 \\
\operatorname{Tg} \text { CO2 eq. }\end{array}$} & \multirow[b]{2}{*}{ Difference } \\
\hline & & Scenario 1 & Scenario 2 & \\
\hline Enteric fermentation, $\mathrm{CH} 4$ & 1.58 & 1.45 & 1.45 & 0 \\
\hline Cattle & 1.40 & 1.28 & 1.28 & 0 \\
\hline Other species & 0.18 & 0.17 & 0.17 & 0 \\
\hline Manure management & 0.79 & 0.66 & 0.63 & 0.03 \\
\hline $\mathrm{N} 2 \mathrm{O}$ & 0.51 & 0.38 & 0.38 & 0 \\
\hline Cattle & 0.24 & 0.15 & 0.15 & 0 \\
\hline Other species & 0.26 & 0.23 & 0.23 & 0 \\
\hline $\mathrm{CH} 4$ & 0.28 & 0.28 & 0.26 & 0.03 \\
\hline Cattle & 0.12 & 0.14 & 0.13 & 0.01 \\
\hline Other species & 0.15 & 0.15 & 0.13 & 0.02 \\
\hline Soils, N2O & 3.23 & 3.35 & 2.85 & 0.50 \\
\hline Mineral fertilisers & 0.91 & 1.05 & 1.04 & 0.01 \\
\hline Manure & 0.52 & 0.44 & 0.44 & 0 \\
\hline Sewage sludge & $0.6 \times 10^{-4}$ & $1.8 \times 10^{-3}$ & $1.8 \times 10^{-3}$ & 0 \\
\hline Organic soils & 1.05 & 1.10 & 0.61 & 0.49 \\
\hline Crop residue & 0.16 & 0.17 & 0.17 & 0 \\
\hline $\mathrm{N}$ fixation & $3.9 \times 10^{-3}$ & 0.01 & 0.01 & 0 \\
\hline Indirect emissions & 0.60 & 0.59 & 0.59 & 0 \\
\hline Total & 5.60 & 5.47 & 4.94 & 0.53 \\
\hline$\%$ mitigation & & & 9.7 & \\
\hline
\end{tabular}




\section{Regina, K. et al. Greenhouse gas mitigation in Finnish agriculture}

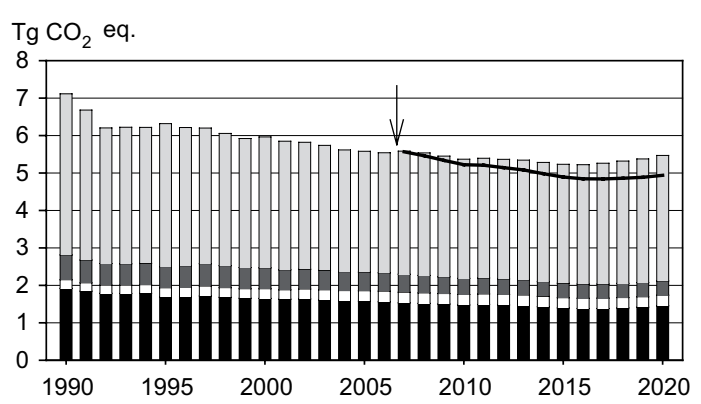

Fig. 2 Agricultural greenhouse gas emissions in Scenario 1: $\mathrm{CH}_{4}$ from enteric fermentation (black), $\mathrm{CH}_{4}$ from manure management (white), $\mathrm{N}_{2} \mathrm{O}$ from manure management (dark grey) and $\mathrm{N}_{2} \mathrm{O}$ from soils (light grey). Projected total emissions in Scenario 2 are marked as a line. The start of projected emissions is marked with an arrow. The difference between the scenarios is mainly due to difference in $\mathrm{N}_{2} \mathrm{O}$ emissions from soils.

mals decreased by $28 \%$ and the emission factor for enteric fermentation increased by $18 \%$ resulting to a $8.6 \%$ decrease in the emissions from this category in 2005-2020. The $\mathrm{N}_{2} \mathrm{O}$ emissions from manure management of all animals would decrease by $25 \%$ based on the estimated decrease in animal numbers. The predicted changes in the agricultural area (increased total area and area of organic soils) and a resulting increase in fertiliser use would cause a $3.7 \%$ rise in the $\mathrm{N}_{2} \mathrm{O}$ emissions from soils.

\section{GHG emission estimates in Scenario 2}

According to Scenario 2, the emissions would decrease $11.5 \%$ compared to those in 2005 being $4.94 \mathrm{Tg} \mathrm{CO}$ equivalents in 2020 (Table 3). The emissions in 2020 would be $9.7 \%$ lower in the policy scenario compared to the baseline scenario. The $\mathrm{CH}_{4}$ emissions from enteric fermentation and $\mathrm{N}_{2} \mathrm{O}$ emissions from manure management in the future years would be the same in both scenarios since the animal numbers were the same and no mitigation measures targeted to these emissions were assumed. The increase in biogas production would reduce $\mathrm{CH}_{4}$ emissions from manure manage- ment by $3 \%$ or $0.02 \mathrm{Tg} \mathrm{CO}_{2}$ eq. which is $0.4 \%$ of the total emissions of the sector. The reduction in the area of cultivated organic soils together with increasing grass cultivation on the remaining area would reduce the $\mathrm{N}_{2} \mathrm{O}$ emissions from organic soils by $45 \%$ by 2020 . There was a slight decrease in emissions from mineral fertilisers compared to the baseline scenario but these emissions, however, were $14 \%$ higher than in 2005 . No other changes in soil emissions were expected on the basis of the selected modelling assumptions since the amount of manure was not assumed to change and the amount of crop residues changed very little.

\section{Uncertainties of the emission estimates}

The total uncertainty of the reported emissions from agriculture in 1990-2006 is estimated to be -32 to $+44 \%$ (Monni et al. 2007). The soil emissions have the highest uncertainty, $71 \%$ for direct emissions and $248 \%$ for indirect emissions. The uncertainty determined for the emissions from enteric fermentation was $32 \%$ and that for $\mathrm{CH}_{4}$ and $\mathrm{N}_{2} \mathrm{O}$ emissions from manure management 16 and $82 \%$, respectively (Statistics Finland 2009). The assumptions made for the emission scenarios naturally increase the uncertainty but we did not attempt to quantify the uncertainties for the future estimates.

\section{Discussion}

The greenhouse gas emissions from agriculture have decreased 22\% during 1990-2006. The decrease is mainly due to decreases in animal numbers, area of organic soils and nitrogen fertiliser use. The decline in cattle numbers is joint outcome of increasing milk yields per dairy cow and national milk quota. As the same total output of milk can be produced by a decreasing number of dairy cows the number of bovine animals can be decreased. A drawback of this development is the increase of emission factors due to increase in animal weights. If our estimate of 
Vol. 18 (2009): 477-493.

the animal weights is an overestimate it is possible for the future emissions from enteric fermentation to decrease more than estimated here. Use of nitrogen in mineral fertilisers has decreased 35\% during 1990-2006 which partly results from efforts in reducing nutrient pollution in watercourses. Thus, reducing nutrient load to watercourses has been beneficial also for mitigating climate change. The use of $\mathrm{N}$ fertilisers is well optimized at the moment but we see from the results of the Dremfia model that there is a risk of increasing fertiliser use if the prices of agricultural products are high enough. The modelled increase of $18 \%$ in the use of $\mathrm{N}$ in fertilisers would be possible even with taking into account the restrictions by the nitrates directive. The modelling results indicate that the emissions as a whole are likely to continue decreasing in the near future but may even increase at some stage if the agricultural area and animal production are let to grow as a result of positive market prospects and market liberalization and if no effective mitigation policy is applied. This development would result to a modest $2.3 \%$ decrease of emissions in 2005-2020. Thus, if no measures were taken aiming at reduction of GHG emissions, we can not expect the emissions to decrease as has occurred since 1990.

The mitigation measures selected for Scenario 2 would mainly affect the $\mathrm{N}_{2} \mathrm{O}$ emissions from soils. As the soil emissions are $60 \%$ of the total agricultural emissions in Finland, a mitigation strategy concentrating on soils would be justified. Organic soils are only $12 \%$ of the total cultivated area in Finland but they are responsible for $30 \%$ of the soil emissions of $\mathrm{N}_{2} \mathrm{O}$. Concerning the mitigation measure 1), it is worth noting that new fields have been cleared from forest or peat soils lately due to the increased demand of new area for manure spreading in certain areas and increase in farm size in general. This development may lead to the emissions from soils being even higher in 2020 than in 2005 if no restrictions for taking new area to cultivation will be applied. To efficiently reduce the soil emissions, part of the organic fields should also be taken out of production. At the nation's scale this would be possible since, taking into account the need of food production, there is 500000 ha of excess field area. Organic soils are, however, unevenly distributed over the country which puts farmers to unequal position in this respect. Risk of negative socioeconomic effects and willingness to keep landscapes open has restricted this kind of mitigation activities.

The area that is removed from production is most likely abandoned (formation of grassland) or afforested. According to the results of a recent peat research programme, afforestation of cultivated organic soils reduces the emissions but does not turn them to sinks (MMM 2007). Taking the fields to peat production was considered as the most climate friendly option but due to the peat properties and small size of the fields that is not a truly realistic option. In this study we did not consider the emissions from these areas after their land use class changes but according to MMM (2007) the other land use options have smaller emissions. Thus, in addition to the lower agricultural emissions we can expect lower emissions from the following land use regardless of the type of the land use. If we consider the agriculture-related carbon dioxide emissions from organic soils that are reported in the LULUCF sector an additional $1 \mathrm{Tg} \mathrm{CO}$ eq. emission reduction would be achieved if the area was reduced and grass cultivation was increased on these soils as assumed here (results not shown).

Somewhat surprisingly, the simulation showed that restricting the cropland area to the level of 2006 would not affect the development of animal production in the long run; thus in all livestock types the production would be close to that of the baseline scenario. The main explanation for this is the farm size growth which makes it possible for production to shift from organic to mineral soils. Dairy and beef production, however, could be continued to some extent on organic lands if grass cultivation only is allowed, since cereal-based feedstuffs can be purchased on farms. Interestingly, the restricted use of organic lands has little impact on pork production since the overall production decreased by $19 \%$ even in Scenario 1. Hence the part of pork production produced on organic farmlands can be relatively easily shifted to be produced on mineral soils. Decoupled national payments for pigs in fact provide an opportunity to decrease pork production on organic soils with little impact on overall farm 


\section{AGRICULTURAL AND FOOD SCIENCE}

\section{Regina, K. et al. Greenhouse gas mitigation in Finnish agriculture}

incomes or pork production volume. Since the cereals production shifted rather swiftly from organic lands to mineral lands with very little additional changes on cereals area (Table 2) we believe that the Dremfia model is likely to somewhat underestimate the adjustments costs in relocating the cereals cultivation and adjacent pig meat production. Low adjustment costs are probably one reason why the model allocates the decline in pig meat production on regions with high shares of organic soils, such as western Finland. On the other hand, restrictions of the agricultural area in Scenario 2 would lead to higher nutrient balances in many areas which might lead to higher nutrient load to watercourses and to increased GHG emissions from the leached $\mathrm{N}$.

The lower emission factor for grass cultivation compared to cereals enables mitigating the emissions by encouraging the farmers to grow grass on organic soil. This is, indeed, part of Finland's agrienvironmental support policy from 2009 on; the farms can be subsidized for turning from growing of annually ploughed crops to grass cropping on a field situated on organic soil. It is problematic for pig, poultry and cereal production on organic soils since such activities should be driven down and shifted to mineral soils. If we consider just silage and hay production a limited number of farmers are able to take part in this activity. However, almost all farmers are able to cultivate green fallow grasslands or produce grass crops for energy production which may increase the use of the new subsidy. However, funds available for this subsidy are rather limited. Nevertheless, increasing low intensity grasslands would most likely favour water protection and biodiversity which have been the priorities in Finnish agri-environmental policy.

The effect of biogas production seems to be of minor importance in the mitigation estimates. One benefit of biogas as a mitigation practice is that the reductions are seen in the emissions reported as agricultural emissions whereas the production of field biomasses may even increase the agricultural emissions due to the increased need of cropland area and fertiliser use. Besides the estimated effect of biogas on emissions from manure management there are the additional savings in fossil fuel that are seen as reduction in the emissions of the energy sector. If the biogas replaced fuel oil e.g. in grain driers on farms the resulting emission reduction in the energy sector would be $0.32 \mathrm{Tg} \mathrm{CO}_{2}$ eq. which is about $6 \%$ of the projected total GHG emissions from agriculture in 2020. There are, of course, some other measures that have effects on the emissions reported in the energy sector. For example reduced energy use on farms or reduced use of mineral fertilisers affect these emissions and reductions can be achieved e.g. by advisory programs.

Our approach has certain strengths that facilitate relevant support for climate policy design and decision making but it also includes certain weaknesses to be improved in forthcoming research efforts. We explicitly recognize that the impacts of specific GHG mitigation measures are not independent on other policies and market changes but may be in synergy or in conflict with other policies or farmers' development plans, such as the structural development of farms including farm size growth and spatial concentration of production in order to respond to competition and market demand.

The complex nature of the processes generating greenhouse gas emissions and uncertainties in the development of agricultural policy makes the estimation of future emissions difficult. Currently there is no single model available for directly estimating the effects of different agricultural policy measures into agricultural greenhouse gas emissions in Finland. The selected methodology was to combine two separate models developed independently from each other for different purposes. Because the models did not perfectly fit assumptions of the future development of certain model parameters were made. However, the factors most significantly affecting the emissions were taken into account in all calculations.

A major determinant of the agricultural GHG emissions levels in scenarios 1-2 are the optimistic global food price scenarios as well as assumption on the non-decreasing national production linked payments after 2009. Any significant decrease in national payments for bovine animals, in particular, or long-term economic crisis worsening the meat or milk price prospects would still lead to gradually decreasing production and GHG emissions. In the era of forecasted strong global demand for 
Vol. 18 (2009): 477-493.

food, however, the sustainable way of decreasing agricultural GHG emissions should be based on mitigation measures which do not downscale food production.

Not only food prices, but also input price shocks from the national economy or world markets are likely to have a large influence on agriculture. High energy prices due to climate policies, for example, increase fertiliser and production costs and most likely decrease production volumes in all production lines in agriculture. Sustained high energy prices make energy production from biogas more profitable. On the other hand if there is slow economic growth or economic recession at national economy level that could reduce the opportunity cost of labour and hence keep the agricultural production at a higher level. Increasing agricultural production would pose an extra challenge for Finnish agriculture in reaching the 13\% reduction target in GHG emissions in 2005-2020. According to our analysis the mitigation measures mentioned in the National Climate Strategy, most importantly restrictions on organic lands, are not likely to be sufficient for the $13 \%$ reduction target, if agricultural production remains stable.

\section{Conclusions}

According to the results of this study specific mitigation measures are needed in the agricultural sector in order to respond to the requirements of the climate policies. Measures targeted to the cultivation of organic soils would have the highest impact on the total emissions in Finland. To reach the 13\% mitigation goal determined in the national climate and energy strategy is likely to be difficult without any restrictions or incentives affecting the use of organic soils. Effective measures would both reduce the area of cultivated organic soils and increase the proportion of perennial crops on the remaining area. Such restrictions may have relatively large economic and societal impacts on individual farmers and other stakeholders at local municipality level, not analysed in this study. Hence it may be problematic that climate policy in agriculture hits relatively most a small part of farmlands and farmers. However, we feel that the measures studied here should be taken into use and additional mitigation measures should be developed and analysed in terms of production and GHG mitigation effects. Greenhouse gas mitigation policies should be put into practice so that production is not driven down and national food security is taken care of.

\section{References}

Amon, B., Kryvoruchko, V., Amon, T. \& Zechmeister-Boltenstern, S. 2006. Methane, nitrous oxide and ammonia emissions during storage and after application of dairy cattle slurry and influence of slurry treatment. Agriculture. Ecosystems and Environment 112: 153-162.

Armington, P. 1969. A Theory of Demand for Products Distinguished by Place of Production. IMF Staff $\mathrm{Pa}$ pers 16: 159-178.

Clemens, J., Trimborn, M., Weiland, P. \& Amon, B. 2006. Mitigation of greenhouse gas emissions by anaerobic digestion of cattle slurry. Agriculture, Ecosystems and Environment 112: 171-177.

Council of the European Union 2003. CAP Reform - Presidency compromise (in agreement with the Commission). 10961/03. AGRI 87. AGRIFIN 87. Cited 9 March 2009. Updated 31 Jauary 2009. Available on the internet: http://register.consilium.eu.int/pdf/en/03/st10/ st10961en03.pdf.

Cox, T.L. \& Chavas, J.-P. 2001. An Interregional Analysis of Price Discrimination and Domestic Policy Reform in the U.S. Dairy Sector. American Journal of Agricultural Economics 83: 89-106.

European Commission 2009. Council Regulation (EC) No $72 / 2009$ of 19 January 2009 on modifications to the Common Agricultural Policy. Cited 9 March 2009. Updated 31 January 2009. Available on the internet: http:// eur-lex.europa.eu/JOHtml.do?uri=OJ:L:2009:030:SOM :EN:HTML

Grönroos, J., Mattila, P., Regina, K., Nousiainen, J., Perälä, P., Saarinen, K. \& Mikkola-Pusa, J. 2009. Development of the ammonia emission inventory in Finland - Revised model for agriculture. Finnish Environment Institute 2009. 60 p. Available on the internet: www.environment.fi/publications

Heikkilä, A-M, Riepponen, L. \& Heshmati, A. 2004. Investments in new technology to improve productivity of dairy farms. Paper presented in 91st EAAE seminar "Methodological and Empirical Issues of Productivity and Efficiency Measurement in the Agri-Food System", Rethymno, Greece, September 24-26, 2004.

IPCC 1997. Revised 1996 IPCC Guidelines for National Greenhouse Gas Inventories. Reference manual. Available on the internet: http://www.ipcc-nggip.iges.or.jp/ 


\section{Regina, K. et al. Greenhouse gas mitigation in Finnish agriculture}

public/gl/invs6.htm.

Lehtonen, H. 2001. Principles, structure and application of dynamic regional sector model of Finnish agriculture. Academic dissertation. Systems Analysis Laboratory, Helsinki University of Technology. Publications 98. Agrifood Research Finland, Economic Research, Helsinki. 265 p.

Lehtonen, H. 2004. Impacts of de-coupling agricultural support on dairy investments and milk production volume in Finland. Acta Agriculturae Scandinavica, Section C - Food Economics 1: 46-62.

Lehtonen, H., Aakkula, J. \& Rikkonen, P. 2005. Alternative Policy Scenarios, Sector Modelling and Indicators: A Sustainability Assessment. Journal of Sustainable Agriculture 26: p. 63-93.

Maljanen, M., Hytönen, J., Mäkiranta, P., Alm, J., Minkkinen, K., Laine, J., \& Martikainen, P.J. 2007. Greenhouse gas emissions from cultivated and abandoned organic croplands in Finland. Boreal Environmental Research 12: $133-140$.

MMM 2007. Greenhouse Impacts of the Use of Peat and Peatlands in Finland. Research Programme Final Report. 68 p. Ministry of Agriculture and Forestry 2007. http://www.mmm.fi

MMM 2008a. EU:n maatalouspolitiikan terveystarkastuksesta sopimus. Press release of Ministry of Agriculture and Forestry November 21 2008. Cited 9 March 2009. Updated 28 May 2008. Available on the internet: http:// www.mmm.fi/fi/index/etusivu/terveystarkastus.html (In Finnish)

MMM 2008b. Maidon pohjoinen tuki säilyy jatkossakin tuotantoon sidottuna. Press release from the Ministry of Agriculture and Forestry December 19 2008. Cited 9 March 2009. Updated 19 December 2008. Available on the internet: http://www.mmm.fi/fi/index/ministerio/tiedotteet/081219_pohjoisentuki.html (In Finnish).

Monni, S., Perälä, P. \& Regina, K. 2007. Uncertainty in agricultural $\mathrm{CH}_{4}$ and $\mathrm{N}_{2} \mathrm{O}$ emissions from Finland - possibilities to increase accuracy in emission estimates. Mitigation and adaptation strategies for global change 12: 545-571.

Neufeldt H., Schäfer M., Angenendt E., Li C., Kaltschmitt M. \& Zeddies J. 2006. Disaggregated greenhouse gas emission inventories from agriculture via a coupled economic-ecosystem model. Agriculture, Ecosystems and Environment 112: 233-240.

Neufeld, H. \& Schäfer, M. 2008. Mitigation strategies for greenhouse gas emissions from agriculture using a re- gional economic-ecosystem model. Agriculture, Ecosystems and Environment 123: 305-316.

Oleszczuk, R. Regina, K., Szajdak, L., Höper, H. \& Maryganova, V. 2008. Impact of agricultural utilization of peat soils on the greenhouse gas balance. In: Strack, M. (ed.) Peatlands and climate change. International Peat Society, 2008.

OECD 2008. OECD-FAO Agricultural Outlook 2008-2017. Cited 9 March 2009. Updated 29 May 2008. Available on the internet: www.oecd.org

Penman, J., Kruger, D., Galbally, I., Hiraishi, T., Nyenzi, B., Emmanuel, S., Buendia, L., Hoppaus, R., Martinsen, T., Meijer, J., Miwa, K. and Tanabe, K. 2000. Good Practice Guidance and Uncertainty Management in National Greenhouse Gas Inventories. Intergovernmental Panel on Climate Change. Available on the internet: http:// www.ipcc-nggip.iges.or.jp

Rantamäki-Lahtinen, L., Remes, K. \& Koikkalainen, K. 2002. The investment and production plans in Finnish bookkeeping farms. Agrifood Research Finland, Economic Research (MTTL), Working Papers 4/2002. p. $6-40$.

Rekolainen, S., Posch, M. \& Turtola, E. 1993. Mitigation of agricultural water pollution in Finland: an evaluation of management practices. Water Science Technology 28: $529-538$.

Sands, R.D. \& Leimbach, M. 2003. Modelling agriculture and land use in an integrated assessment framework. Climatic Change 56: 185-210.

Smith P., Martino D., Cai Z., Gwary D., Janzen H., Kumar P., McCarl B., Ogle S., O'Mara F., Rice C, Scholes B, Sirotenko O, Howden M, McAllister T., Pan G., Romanenkov V., Schneider U. \& Towprayoon S. 2007. Policy and technological constraints to implementation of greenhouse gas mitigation options in agriculture. Agriculture, Ecosystems and Environment 118: 6-28.

Soete, L. \& Turner, R. 1984. Technology diffusion and the rate of technical change. The Economic Journal. 94: 612-623.

Statistics Finland, 2009. Greenhouse gas emissions in Finland 1990-2007. National Inventory Report. Available on the internet: http://stat.fi/tup/khkinv/

Takayama, T. \& Judge G.G. 1971. Spatial and Temporal Price and Allocation Models. North-Holland Publishing Company.

Tubiello, F.N. \& Fischer, G. 2007. Reducing climate change impacts on agriculture: Global and regional effects on mitigation, 2000-2080. Technological Forecasting \& Social Change 74: 1030-1056. 
Vol. 18 (2009): 477-493.

\title{
SELOSTE
}

\section{Kasvihuonekaasupäästöjen hillintätoimien vaikutukset maataloudessa vuoteen 2020 mennessä}

\author{
Kristiina Regina, Heikki Lehtonen, Jouni Nousiainen ja Martti Esala
}

MTT

Ennusteita kasvihuonekaasupäästöjen kehityksestä voidaan käyttää apuna ilmastonmuutoksen hillintätoimien suunnittelussa. Jos yksittäisten hillintätoimien vaikutuksista päästöihin on olemassa arvioita, voidaan hillintään varattuja resursseja suunnata vaikutukseltaan tehokkaimpiin politiikkatoimiin. Tässä tarkastelussa verrataan kahta kehitysuraa Suomen maatalouden päästöille vuoteen 2020 mennessä: perusskenaario ilman ilmastonmuutoksen hillintään tähtääviä toimia (Skenaario 1) ja politiikkaskenaario (Skenaario 2). Valitut politiikkatoimet olivat 1) peltopinta-alan säilyttäminen nykytasolla, 2) eloperäisten maiden osuuden pienentäminen, 3) nurmen viljelyn lisääminen eloperäisillä mailla ja 4) biokaasutuotannon lisääminen maatiloilla. Skenaario 1 ennusti maatalouden metaani- ja dityppioksidipäästöjen laskevan 2,3\% aikavälillä 2005-2020, kun taas Skenaariossa 2 päästöt vähenisivät $11,5 \%$ hillintätoimien ansiosta. Tutkimuksessa tarkastelluista keinoista eloperäisten maiden viljelyyn kohdistetut toimet vaikuttavat olevan ilmastonmuutoksen hillinnässä kaikkein tehokkaimpia. 